\title{
A $\beta$ Oligomer-Mediated Long-Term Potentiation Impairment Involves Protein Phosphatase 1-Dependent Mechanisms
}

\author{
Marlen Knobloch, ${ }^{1 \star}$ Mélissa Farinelli, ${ }^{2 *}$ Uwe Konietzko, ${ }^{1}$ Roger M. Nitsch, ${ }^{1 *}$ and Isabelle M. Mansuy ${ }^{2 *}$ \\ ${ }^{1}$ Division of Psychiatry Research, University of Zurich, 8008 Zurich, Switzerland, and ${ }^{2}$ Brain Research Institute, University of Zurich and Department of \\ Biology, Swiss Federal Institute of Technology, 8057 Zurich, Switzerland
}

\begin{abstract}
Amyloid $\beta(\mathrm{A} \beta)$ oligomers are derived from proteolytic cleavage of amyloid precursor protein (APP) and can impair memory and hippocampal long-term potentiation (LTP) in vivo and in vitro. They are recognized as the primary neurotoxic agents in Alzheimer's disease. The mechanisms underlying such toxicity on synaptic functions are complex and not fully understood. Here, we provide the first evidence that these mechanisms involve protein phosphatase 1 (PP1). Using a novel transgenic mouse model expressing human APP with the Swedish and Arctic mutations that render $\mathrm{A} \beta$ more prone to form oligomers ( $\operatorname{arcA} \beta$ mice), we show that the LTP impairment induced by $\mathrm{A} \beta$ oligomers can be fully reversed by PP1 inhibition in vitro. We further demonstrate that the genetic inhibition of endogenous PP1 in vivo confers resistance to $\mathrm{A} \beta$ oligomer-mediated toxicity and preserves LTP. Overall, these results reveal that PP1 is a key player in the mechanisms of $\mathrm{AD}$ pathology.
\end{abstract}

Key words: impairment; PP1; oligomers; A $\beta$-peptide; Alzheimer's disease; LTP

\section{Introduction}

Recent progress in the field of Alzheimer's disease (AD) has provided evidence that amyloid $\beta(\mathrm{A} \beta)$ oligomers rather than $\beta$-amyloid plaques are the major toxic agents in the pathology of the disease (Selkoe, 2002). A $\beta$ oligomers have been demonstrated to disrupt synaptic plasticity and impair memory (Lambert et al., 1998; Walsh et al., 2002; Oddo et al., 2003; Lesne et al., 2006) and are known to accumulate in the brain of AD patients (Takahashi et al., 2002). Therapeutic strategies developed to interfere with $\mathrm{A} \beta$ deposition and clearance have shown initial benefit in $\mathrm{AD}$ patients and rodent models (Hock et al., 2003; Klyubin et al., 2005; Schenk et al., 2005). Neutralization of A $\beta$ toxicity, for instance, was found to reverse memory deficits in a mouse model of AD without altering $\beta$-amyloid plaque load (Dodart et al., 2002).

Many studies have attempted to determine the mechanisms by which $\mathrm{A} \beta$ assemblies disrupt synaptic plasticity and mediate their detrimental effect, but the actual pathways that couple $\mathrm{A} \beta$

Received Jan. 29, 2007; revised May 10, 2007; accepted May 10, 2007.

This work was supported in part by Swiss National Science Foundation Grant 3200B0-112616, the National Center for Competence in Research (NCCR) "Neuronal Plasticity and Repair," and European Union contract LSHM(T-2003-503330 (APOPIS). The laboratory of I.M.M. was supported by the University Zurich, the Swiss Federal Institute of Technology Zurich, the Swiss National Science Foundation, NCCR "Neural Plasticity and Repair," Human Frontier Science Program, the Slack-Gyr Foundation, and the Bitterlin Foundation. We thank Dr. Sandor Vizi for preparing the $\mathrm{I}-1^{*}$ transgenic mice and Karen Duff and Karen Ashe for providing the original PS1 mouse line and the Swedish mouse line. We acknowledge the laboratory of electron microscopy (University of Zurich) for the support with electron microscopy.

${ }^{*}$ M.K. and M.F. contributed equally to this work.

${ }^{\ddagger}$ R.M.N. and I.M.M. contributed equally to this work.

Correspondence should be addressed to either of the following: Isabelle M. Mansuy, Brain Research Institute, University of Zurich/Eidgenössische Technische Hochschule Zürich, Winterthurerstrasse 190, 8057 Zurich, Switzerland, E-mail:mansuy@hifo.unizh.ch; or Roger M. Nitsch, Division of Psychiatry Research, University of Zurich, August Forel-Strasse 1, 8008 Zurich, Switzerland, E-mail: nitsch@bli.unizh.ch.

D0I:10.1523/JNEUROSCI.0395-07.2007

Copyright $\odot 2007$ Society for Neuroscience $\quad$ 0270-6474/07/277648-06\$15.00/0 toxicity to synaptic functions remain only partially understood. A recently identified mechanism implicates specific interactions between $A \beta$ and neurotransmitter receptors such as the NMDA (Snyder et al., 2005; Kelly and Ferreira, 2006) and $\alpha-7$ nicotinic acetylcholine receptors (Oddo and LaFerla, 2006). This mechanism was shown to recruit the $\mathrm{Ca}^{2+}$-dependent protein phosphatase calcineurin (PP2B) (Chen et al., 2002; Snyder et al., 2005; Kelly and Ferreira, 2006), a finding in line with the hypothesis that $\mathrm{Ca}^{2+}$ signaling is disrupted by $\mathrm{A} \beta$ neurotoxicity (Demuro et al., 2005).

To investigate whether other major signaling pathways downstream of the NMDA receptor are implicated in the mechanisms of $\mathrm{A} \beta$ toxicity in vivo, we generated a transgenic mouse model expressing a human amyloid precursor protein (APP) with the Swedish and Arctic mutations ( $\operatorname{arcA} \beta$ mice) that produces a form of $\mathrm{A} \beta$ more prone to yield A $\beta$ oligomers (Knobloch et al., 2007). In these mice, expression of the mutant APP induces punctate intraneuronal $\mathrm{A} \beta$ deposition in several brain areas and severe behavioral deficits before the onset of extracellular $\beta$-amyloid plaque deposition. Using this model, we show here that the overproduction of Arctic $A \beta$ is associated with an age-dependent impairment in hippocampal long-term potentiation (LTP) and synaptic plasticity in vitro that involves protein phosphatase 1 (PP1)-dependent mechanisms. Furthermore, we demonstrate that both the pharmacologic and genetic inhibition of PP1 in vitro and in vivo reverse the defect in synaptic plasticity induced by $\mathrm{A} \beta$ oligomers. These results strongly support a major role for PP1 in the mechanisms of $\mathrm{A} \beta$ oligomer-mediated toxicity and demonstrate its reversibility in adult animals.

\section{Materials and Methods}

Animals. ArcA $\beta$ mice, APPSwe/PS1 mice, and I- $1^{\star}$ mutant mice were obtained by breeding as described previously (Holcomb et al., 1998; 
Genoux et al., 2002; Michalon et al., 2005; Knobloch et al., 2007). ArcA $\beta$ mice express human APP 695 carrying both the Swedish (K670N; $\mathrm{M} 671 \mathrm{~L}$ ) and the Arctic (E693G) mutations in a single construct under the control of the prion protein promoter. APPSwe/PS1 mice carry a human APP with the Swedish mutation and a mutant presenilin 1 (M146L). I- $1^{\star}$ mutant mice carry a transgene expressing an rtTA2 factor under the control of the calcium/calmodulin-dependent kinase II $\alpha$ $(\mathrm{CaMKII} \alpha)$ promoter and a transgene carrying a tetO promoter fused to $\mathrm{I}^{\star}$ cDNA. Mice were kept under standard housing conditions on a reversed $12 \mathrm{~h}$ light/dark cycle with food and water ad libitum. Seven to nine days before the experiments, I-1* mutant mice and control littermates (carrying only the tetO-I-1* transgene) were fed doxycycline (WestWard Pharmaceuticals, Eatontown, NJ) at $6 \mathrm{mg} / \mathrm{g}$ of food. All animal experiments were performed in accordance with guidelines of the Swiss veterinary cantonal office (licenses $\mathrm{Nr}$ 150/06 and 123/04).

Electrophysiological recordings. Mice were anesthetized with isoflurane and then decapitated. Heads were immediately immersed in ice-cold freshly prepared artificial CSF (aCSF) for at least 2 min before brain extraction. Acute slices (400 $\mu \mathrm{m}$ thick) were prepared with a vibratome (VT 1000S; Leica Microsystems, Bannockburn, IL) in ice-cold gassed aCSF. Sections were incubated in aCSF at $34^{\circ} \mathrm{C}$ for $20 \mathrm{~min}$ and then kept at room temperature for at least $1 \mathrm{~h}$ before recording. Recording was performed in an interface chamber continuously flowed with aCSF at 1.1 $\mathrm{ml} / \mathrm{min}$. A monopolar electrode was placed in the Schaffer collaterals, and stimulation was applied at $0.033 \mathrm{~Hz}$ with stimulus intensity ranging from 20 to $80 \mu \mathrm{A}$, yielding evoked field EPSPs (fEPSPs) of $0.2-0.5 \mathrm{~V}$. fEPSPs were recorded in the stratum radiatum using a borosilicate micropipette filled with aCSF. The signal was amplified with an Axopatch 200B amplifier (Molecular Devices, Union City, CA), digitized by a Digidata 1200 interface (Molecular Devices) and sampled at $10 \mathrm{kHz}$ with Clampex 8.2 (Molecular Devices). aCSF was composed of the following (in mM): $119 \mathrm{NaCl}, 11 \mathrm{D}$-glucose, $1.3 \mathrm{MgCl}_{2} \cdot 6 \mathrm{H}_{2} \mathrm{O}, 1.3 \mathrm{NaH}_{2} \mathrm{PO}_{4}, 2.5$ $\mathrm{KCl}, 2.5 \mathrm{CaCl}_{2}, 26 \mathrm{NaHCO}_{3}$, gassed with $\mathrm{O}_{2} / \mathrm{CO}_{2}$ (95/5\%) at least $20 \mathrm{~min}$ before use and throughout the experiment. Baseline was recorded for a minimum of 20 min or until stable. Plasticity was then induced by stimulation with either $1 \mathrm{~Hz}$ for $15 \mathrm{~min}$ (900 pulses), $2 \mathrm{~Hz}$ for $10 \mathrm{~min}$ (1200 pulses), $5 \mathrm{~Hz}$ for $3 \mathrm{~min}$ (900 pulses), $10 \mathrm{~Hz}$ for $1.5 \mathrm{~min}$ (900 pulses), or $100 \mathrm{~Hz}$ for three trains of $1 \mathrm{~s}$ tetanus separated by $20 \mathrm{~s}$. Data were analyzed by measuring the slope of individual fEPSPs at $1-1.5 \mathrm{~ms}$ after the stimulus pulse by linear fitting using Clampfit (Molecular Devices). The frequency-dependent plasticity curve (BCM curve) was built by determining mean fEPSP slopes over $10 \mathrm{~min}$ starting $35 \mathrm{~min}$ after stimulation (according to Jouvenceau et al., 2006).

Reverse transcription and quantitative real-time PCR. Total RNA was isolated from frozen hippocampi of 6-month-old $\operatorname{arcA} \beta$ mice and wildtype littermates ( $n=5$ for each) with TRIzol (Invitrogen, Carlsbad, CA) and cleaned up with RNeasy Mini kit (Qiagen, Valencia, CA). Firststrand cDNA was synthesized using the SuperScript First-Strand Synthesis System for RT-PCR (Invitrogen) according to the manufacturer's protocol. Real-time PCR was performed on TaqMan (ABI PRISM 7700 SDS) using SYBR Green (Applied Biosystems, Foster City, CA). Primer sequences were as follows: NMDA receptor subunit $2 \mathrm{~B}$ (NR2B) forward (for.), AAGACAAGGGCCGATTCATG; reverse (rev.), GCAAAGGAGCTCTCACCAGC; CaMKII for., AGTCAGAGGAGACCCGCGT; rev., TGTGGAAGTGGACGATCTGC; glutamate receptor 1 (GluR1) for., CAATGTGGCAGGCGTGTTC; rev., TCGATTAAGGCAACCAGCATG; Syn.physin for., AAGGTGCTGCAGTGGGTCTTT; rev., CGAAGCTCTCCGGTGTAGCT; Zif268 for., CGAGAAGCCTTTTGCCTGTG; rev., TGGTATGCCTCTTGCGTTCA; Arc for., TGGAGGGAGGTCTTCTACCGT; rev., TATTTGCCGCCCATGGACT; $\beta$-actin for., TACTCTGTGTGGATCGGTGGC; rev., TGCTGATCCACATCTGCTGG; glyceraldehyde-3-phosphate dehydrogenase (GAPDH) for., GGCATCTTGGGCTACACTGAG; rev., CGAAGGTGGAAGAGTGGGAG.

Data analysis was performed according to the $\Delta \Delta \mathrm{Ct}$ method, normalized to $\beta$-actin and GAPDH. Statistical analysis was performed on the $\Delta$ Ct values using Student's $t$ test.

Passive immunization. Three-month-old $\operatorname{arc} \mathrm{A} \beta$ mice were immunized with a single intraperitoneal injection $(10 \mathrm{mg} / \mathrm{kg})$ of either purified $6 \mathrm{E} 10$
(Signet, Dedham, MA) or negative control antibody for mouse $\operatorname{IgG}_{1}(\mathrm{Lab}$ Vision, Fremont, CA) $48 \mathrm{~h}$ before slice preparation.

Tautomycin application. Slices from 3-month-old $\operatorname{arcA} \beta$ mice, wildtype littermates, and APPSwe/PS1 mice were bathed in normal aCSF or aCSF containing $1 \mathrm{~nm}$ tautomycin (Sigma, St. Louis, MO) for at least $1 \mathrm{~h}$ before recording.

PP1 activity assay. Activity of recombinant PP1 (New England Biolabs, Beverly, MA) and calcineurin (Biomol, Plymouth Meeting, PA) was measured with and without $1 \mathrm{~nm}$ tautomycin using a modified Biomol Green Assay kit (Biomol).

Western blot analysis of phospho-CaMKII levels. Mice were perfused transcardially with ice-cold PBS, and hippocampi were dissected and immediately frozen in dry ice. Crude synaptic membrane fractions were prepared according to Genoux et al. (2002). Equal amount of proteins was loaded and separated by SDS-PAGE, transferred to a nitrocellulose membrane, and blocked in TBS containing 1\% BSA and 0.1\% Triton X-100. Primary antibodies [anti-phospho-CaMKII antibody, 1:1000 (Millipore, Billerica, MA); anti-total CaMKII antibody, 1:10,000 (Millipore); and anti- $\beta$-actin antibody, 1:5000 (Abcam, Cambridge, MA)] were incubated overnight at $4^{\circ} \mathrm{C}$, and the corresponding secondary antibodies were incubated for $1.5 \mathrm{~h}$ at room temperature. Commercial ECL (GE Healthcare, Piscataway, NJ) was used for the detection of chemiluminescence. Densitometric analysis was performed using the free downloadable ImageJ software (http://rsb.info.nih.gov/ij/).

$A \beta$ oligomer preparation and application. $\mathrm{A} \beta$ oligomers were prepared according to Klein (2002). Synthetic A $\beta_{1-42}$ (Bachem, King of Prussia, PA) was dissolved in Hexafluor2-propanol (HFIP), aliquoted, and kept at $-80^{\circ} \mathrm{C}$ after evaporation of HFIP. A $\beta$ oligomers were prepared freshly by dissolving the above peptide film with DMSO and diluting it into cold F12 medium without phenol red to yield a $100 \mu \mathrm{M}$ stock. This preparation was incubated at $4^{\circ} \mathrm{C}$ for $24 \mathrm{~h}$ and centrifuged at $14,000 \times g$ for 10 $\min$ at $4^{\circ} \mathrm{C}$, and the supernatant was further used for electrophysiological experiments according to Wang et al. (2002). Slices were bathed for at least $1 \mathrm{~h}$ in aCSF containing either $\mathrm{A} \beta$ oligomers (1:200 diluted) or, as a control, phenol red-free F12 medium only (1:200 diluted). To prevent a washout of $A \beta$ oligomers during recording, the aCSF used for perfusion contained a 1:400 dilution of $A \beta$ oligomers/phenol red-free F12, respectively. Each $\mathrm{A} \beta$ oligomer preparation was used for one $\mathrm{I}-1^{\star}$ mutant mouse and a corresponding control in parallel, measured in a blinded manner.

Electron microscopy. The $\mathrm{A} \beta$ oligomer preparation was controlled by electron microscopy. Five microliters of the above supernatant were adsorbed onto glow-discharged, 300-mesh carbon-coated Formvar grids for 2-3 min, negatively stained with $2 \%$ phosphorwolfram acid for $45 \mathrm{~s}$, and viewed with a Philips CM12 scanning transmission electron microscope.

\section{Results}

\section{Severe impairment in synaptic plasticity in $\operatorname{arcA} \beta$ mice}

To evaluate the effect of $\operatorname{arcA} \beta$ on synaptic plasticity, we first measured hippocampal LTP in area CA1 in vitro by recording fEPSPs in acute slices from adult arcA $\beta$ mice and wild-type littermates after $100 \mathrm{~Hz}$ stimulation. LTP was severely impaired in slices from 3.5- and 7.5-month-old arcA $\beta$ mice (Fig. $1 A, B)(p<$ 0.001 ; repeated-measurement ANOVA), with fEPSPs returning to baseline within $10 \mathrm{~min}$ after LTP induction. The LTP deficit was not caused by impaired synaptic transmission, because basal transmission was normal in the transgenic slices (Fig. $1 A, B$, inset). It did not result from a developmental defect caused by transgene expression either, because both LTP (Fig. 1C) and basal synaptic transmission (Fig. $1 C$, inset) were normal in slices from 1 -month-old mice, consistent with the fact that $\mathrm{A} \beta$ accumulation is not detectable at this age despite high expression of mutant APP (Knobloch et al., 2007). We confirmed that the LTP deficit was caused by $\mathrm{A} \beta$ oligomers by showing that it could be reversed with a single dose of an antibody directed against the $A \beta$ sequence (6E10) administered to the animals $48 \mathrm{~h}$ before LTP induction (supplemental Fig. 1, available at www.jneurosci.org as supple- 
mental material). The antibody treatment restored LTP in transgenic slices to $\sim 85 \%$ level of potentiation compared with slices from wild-type littermates. A control antibody of the identical IgG class against a nonrelated antigen failed to rescue LTP (supplemental Fig. 1, available at www.jneurosci.org as supplemental material). In addition to a deficit in plasticity at high induction frequency (100 Hz for LTP), stimulation frequencies of 5 and $10 \mathrm{~Hz}$ also showed reduced fEPSP potentiation in slices from $\operatorname{arcA} \beta$ mice compared with wild-type slices. Plasticity at 1 or $2 \mathrm{~Hz}$ stimulation frequency was not changed (Fig. 2D). These results reveal a deficit in plasticity across a wide range of stimulation frequencies with a shift of responses toward synaptic depression.

To examine whether candidate genes involved in synaptic signaling may underlie the impairment in plasticity induced by $\mathrm{A} \beta$ oligomers, we measured the level of expression of several candidate genes by real-time reverse transcription (RT)-PCR. Hippocampal expression of synaptophysin, a synaptic vesicle protein involved in neurotransmitter release, the NR2B and GluR1 subunits of the NMDA and AMPA receptors critical for glutamatergic neurotransmission, or CaMKII, a major protein kinase necessary for the induction of LTP (Lisman et al., 2002), was not altered in $\operatorname{arcA} \beta$ mice (Fig. 1D). However, because intracellular $\mathrm{Ca}^{2+}$ signaling is altered by $\mathrm{A} \beta$ oligomers, it is likely that $\mathrm{Ca}^{2+}$-dependent posttranslational processes such as protein phosphorylation are perturbed. Therefore, we examined whether phosphorylation of CaMKII is changed in $\operatorname{arcA} \beta$ mice. Western blot analyses revealed a decrease in the level of phosphorylated CaMKII in synaptic membranes from $\operatorname{arcA} \beta$ mice (supplemental Fig. 2, available at www.jneurosci.org as supplemental material), suggesting a perturbation in protein kinase/ phosphatase pathways. Furthermore, the expression of transcription factors rapidly activated after neuronal activity and required for LTP, arg3.1/arc and zif268 (Worley et al., 1991; Link et al., 1995; Guzowski et al., 2000), was significantly reduced in $\operatorname{arcA} \beta$ mice (Fig. $1 D)[p<$ 0.05 ; $t$ test; mean and range percentage change versus wild type (wt): arg3.1, 67\% (58-78\%); zif268, 52\% (45-61\%)]. These results therefore indicate that $\mathrm{A} \beta$ oligomers alter protein phosphorylation and the activation of immediate early genes (IEGs).

\section{In vitro inhibition of $\mathrm{PP} 1$ reverses $\mathrm{A} \beta$ oligomer-mediated plasticity impairment}

Because PP1 is a major protein phosphatase in neurons that negatively regulates intracellular signaling downstream from the NMDA receptor (including CaMKII) and modulates hippocampal LTP (Jouvenceau et al., 2006; Mansuy and Shenolikar, 2006), we examined whether it might be involved in the deficit in plasticity induced by A $\beta$ oligomers. PP1 was inhibited pharmacologically in acute hippocampal slices from $\operatorname{arc} \mathrm{A} \beta$ mice and wild-type littermates using the selective inhibitor tautomycin ( $1 \mathrm{nM})$, and the effect on plasticity was examined across several stimulation frequencies. Remarkably, PP1 inhibition was found to fully re-
B 7.5 months

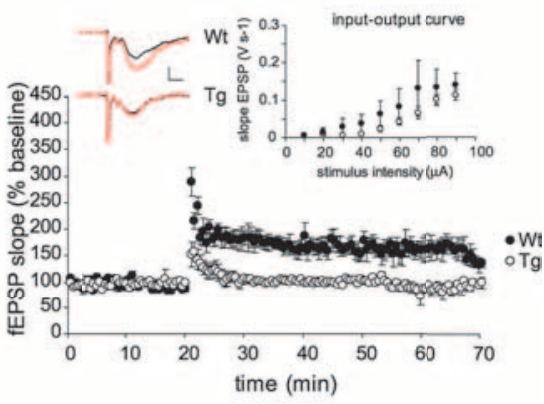

D

mRNA expression

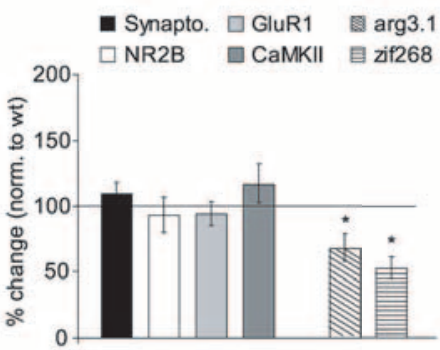

verse the deficit in plasticity observed at 5,10 , or $100 \mathrm{~Hz}$ in $\operatorname{arcA} \beta$ slices (Fig. $2 A, D)(p<0.05$; repeated-measurement ANOVA) but had no effect on plasticity in wild-type slices (Fig. $2 B)(p=0.3$; repeated-measurement ANOVA). This rescuing effect resulted specifically from PP1 inhibition and did not involve the protein phosphatase calcineurin because only PP1 activity was significantly inhibited by $1 \mathrm{~nm}$ tautomycin (Fig. 2C), confirming that PP1dependent mechanisms are involved in the plasticity deficit.

To confirm the rescuing effect of PP1 inhibition observed in $\operatorname{arcA} \beta$ mice, we examined whether it could be reproduced in another transgenic mouse model of AD. We tested the well established APPSwe/PS1 model that expresses human APP carrying the Swedish mutation and a mutated Presenilin 1 and exhibits an early AD pathology associated with marked behavioral deficits (Holcomb et al., 1998). Similarly to $\operatorname{arcA} \beta$ mice, CA1 hippocampal LTP was severely impaired in 3-month-old APPSwe/PS1 animals and was significantly rescued by PP1 inhibition ( $1 \mathrm{nM}$ tautomycin) (Fig. $2 E)$ ( $p<0.05$; repeated-measurement ANOVA). The rescue was however less pronounced than in $\operatorname{arcA} \beta$ mice, possibly because of higher production of the more toxic $\mathrm{A} \beta_{1-42}$ as a result of the presenilin mutation in APPSwe/PS1. Together, these results strongly suggest that PP1 is a critical factor in the course of $\mathrm{A} \beta$-mediated toxicity.

\section{Inhibition of endogenous $\mathrm{PP} 1$ in vivo confers resistance to $\mathrm{A} \boldsymbol{\beta}$ oligomer-mediated toxicity}

To assess whether the detrimental effect of PP1 is also reversible in vivo, we examined whether inhibition of endogenous PP1 be- 
A

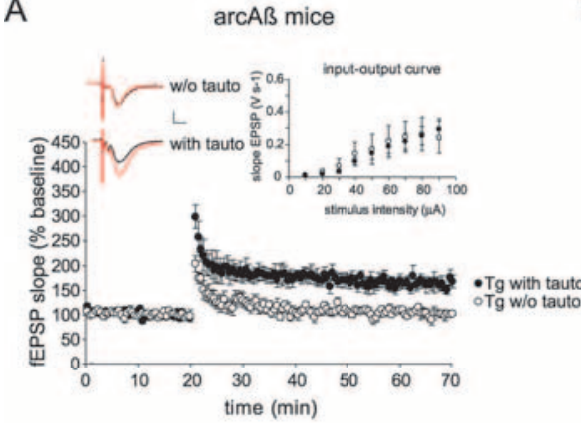

C PP1 activity D Frequency1nM Tautomycin response curve
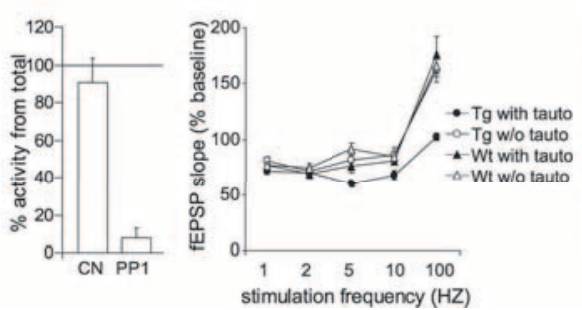

E
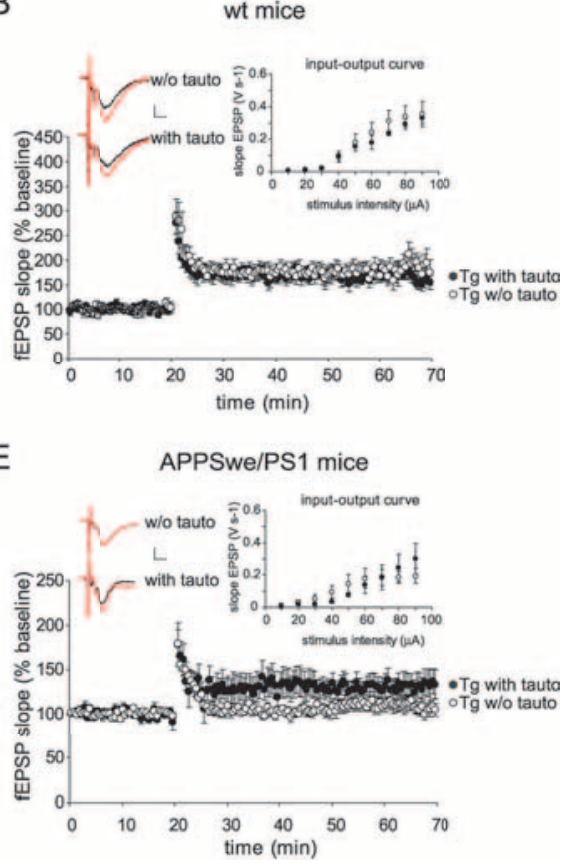

Figure 2. In vitro inhibition of PP1 reverses $A \beta$ oligomer-mediated LTP impairment. $A, B, P P 1$ is inhibited by bath application of $1 \mathrm{~nm}$ tautomycin (tauto) in slices from 3-month-old arcA $\beta$ mice and wild-type littermates. Tautomycin fully reverses the LTP deficit in slices from $\operatorname{tg}$ mice $(n=5)$ but has no effect in wt ( $n=5$ mice). It also does not change basal transmission (right insets). Left insets, Individual fEPSP traces for tg and wt mice before (black) and after (red) LTP induction. Calibration: $0.3 \mathrm{mV}, 5 \mathrm{~ms}$. $\boldsymbol{C}$, Phosphatase activity assays showing that $1 \mathrm{~nm}$ tautomycin specifically inhibits the activity of recombinant PP1 but not of recombinant calcineurin. $\boldsymbol{D}$, Frequency-response curve showing mean fEPSP slopes over 10 min starting 35 min after stimulation with $1,2,5,10$, and $100 \mathrm{~Hz}$ in slices from $\mathrm{tg}$ and wt mice treated or not with tautomycin ( $n=3-5$ slices per condition and frequency). E, PP1 inhibition with $1 \mathrm{~nm}$ tautomycin also reverses the LTP deficit seen in 3-month-old APPSwe/PS1 mice, another mouse model of $A D(n=5 \mathrm{tg})$. Error bars represent SEM. CN, Calcineurin; Tg, transgenic; w/0, without.

fore exposure to $\mathrm{A} \beta$ oligomers confers resistance to $\mathrm{A} \beta$ oligomermediated toxicity. We took advantage of a transgenic mouse model in which PP1 is selectively inhibited (by $40-60 \%$ ) in forebrain neurons by expression of a constitutively active form of the PP1 inhibitor-1 (I-1*) (Genoux et al., 2002; Michalon et al., 2005). Acute slices from adult $I-1^{\star}$ transgenic mice were exposed to $\mathrm{A} \beta$ oligomers produced from synthetic $\mathrm{A} \beta_{1-42}$. This preparation of $\mathrm{A} \beta$ oligomers contained globular $\mathrm{A} \beta$ assemblies of 7-12 nm diameter (Fig. 3A), as previously described (Klein, 2002). To verify that our preparation of $\mathrm{A} \beta$ oligomers had the reported inhibitory effect on LTP (Wang et al., 2002), we bathed slices from wild-type mice in aCSF containing $\mathrm{A} \beta$ oligomers $(0.5 \mu \mathrm{M}$ of the initial peptide) or normal aCSF. As expected, $A \beta$ oligomers strongly impaired the induction of LTP in slices from wild-type mice, and fEPSPs returned to baseline within $10 \mathrm{~min}$ after tetanic stimulation (Fig. 3B). Likewise, A $\beta$ oligomers impaired LTP in slices from I- ${ }^{\star}$ control littermates (Fig. $\left.3 C\right)(p<0.05$; repeatedmeasurement ANOVA). However, in slices from I- $1^{\star}$ transgenic mice, $A \beta$ oligomers did not prevent the induction of LTP, which was robust and stable (Fig. $3 D)(p=0.6$; repeated-measurement ANOVA comparing LTP with and without A $\beta$ oligomers). These results therefore indicate that PP1 inhibition in vivo confers protection against $\mathrm{A} \beta$ oligomer-mediated toxicity.

\section{Discussion}

This study demonstrates that the inhibitory effects of $\mathrm{A} \beta$ oligomers on hippocampal LTP in the adult brain are reversible and that normal LTP can be restored by PP1 inhibition in vitro in independent mouse models of $\mathrm{AD}(\operatorname{arcA} \beta$ mice and APPSwe/PS1 mice). It also reveals that in addition to LTP induced by $100 \mathrm{~Hz}$ stimulation, A $\beta$ oligomers perturb synaptic plasticity in the hippocampus at intermediate frequencies ( 5 and $10 \mathrm{~Hz}$ ) and induce a general shift in synaptic responses toward depression that, similar to LTP, can be fully reversed by PP1 inhibition. Endogenous PP1 inhibition in vivo is further shown to prevent the impairment of LTP induced by $\mathrm{A} \beta$ oligomers, providing strong evidence that PP1 is a critical player in the mechanisms of $\mathrm{A} \beta$ oligomer-mediated toxicity.

Although the mechanisms of $\mathrm{A} \beta$ action are not fully understood, our results provide evidence that, in addition to involving PP1-dependent processes, they also implicate CaMKII and IEGs. CaMKII, arg3.1, and zif268 are traditionally known as key molecules in the mechanisms of LTP and memory formation (Jones et al., 2001; Lisman et al., 2002; Tzingounis and Nicoll, 2006) and have also been implicated in $\beta$-amyloid pathology (Dickey et al., 2003; Lin et al., 2004). The novel correlation that our results reveal between these molecules and PP1 suggests that they may be downstream targets of PP1-dependent pathways perturbed by $\mathrm{A} \beta$ oligomers. This may involve direct dephosphorylation of CaMKII by PP1, because CaMKII is a known target of PP1 (Strack et al., 1997) and could account for the alteration in plasticity in our model, which is severe, despite normal expression of NMDA and AMPA receptors and synaptophysin. Interestingly, PP1 inhibition in vivo has been shown to increase CaMKII phosphorylation, shift hippocampal plasticity toward potentiation (Jouvenceau et al., 2006), and reverse cognitive deficits in aged mice (Genoux et al., 2002). The present results significantly extend these previous findings by demonstrating the relevance of these PP1-dependent pathways in the mechanisms of $\mathrm{AD}$. The present findings further underscore the implication of dysfunctional protein phosphorylation in $\mathrm{AD}$ pathology and highlight the importance of protein phosphatases in this pathology. The importance of their contribution is clearly reflected by the fact that the deficits in plasticity associated with the pathology are fully reversible, just like protein phosphorylation is. Because PP1 is a major protein phosphatase in neuronal cells, multiple targets and pathways are likely to be modified, such as phosphorylation or trafficking of glutamate receptors, as recently shown in primary neurons and organotypic brain slices from AD mouse models (Snyder et al., 2005; Hsieh et al., 2006).

Finally, the severe LTP impairment observed in young $\operatorname{arcA} \beta$ mice ( 3 months) when no $\beta$-amyloid plaques are detectable supports the hypothesis that oligomeric $\mathrm{A} \beta$ species are major contributors to synaptic failure in AD (for review, see Rowan et al., 2003). The rescue of LTP achieved with a single dose of an antibody directed against the $\mathrm{A} \beta$ sequence confirms this hypothesis and suggests that such antibodies may be useful in immunotherapeutic strategies against AD (Rowan et al., 2005). In our model, the reduced arg3.1 and zif268 expression occurs before any detectable extracellular $\beta$-amyloid deposition, supporting the evi- 
dence that disruption of synaptic plasticity is an early event in the course of the disease. Overall, these results point to $\mathrm{PP} 1$ as a promising target for the development of potential therapeutic approaches against $\mathrm{A} \beta$-mediated toxicity in $\mathrm{AD}$.

\section{References}

Chen QS, Wei WZ, Shimahara T, Xie CW (2002) Alzheimer amyloid beta-peptide inhibits the late phase of long-term potentiation through calcineurin-dependent mechanisms in the hippocampal dentate gyrus. Neurobiol Learn Mem 77:354-371.

Demuro A, Mina E, Kayed R, Milton SC, Parker I, Glabe CG (2005) Calcium dysregulation and membrane disruption as a ubiquitous neurotoxic mechanism of soluble amyloid oligomers. J Biol Chem 280:17294-17300.

Dickey CA, Loring JF, Montgomery J, Gordon MN, Eastman PS, Morgan D (2003) Selectively reduced expression of synaptic plasticity-related genes in amyloid precursor protein + presenilin-1 transgenic mice. J Neurosci 23:5219-5226.

Dodart JC, Bales KR, Gannon KS, Greene SJ, DeMattos RB, Mathis C, DeLong CA, Wu S, Wu X, Holtzman DM, Paul SM (2002) Immunization reverses memory deficits without reducing brain Abeta burden in Alzheimer's disease model. Nat Neurosci 5:452-457.

Genoux D, Haditsch U, Knobloch M, Michalon A, Storm D, Mansuy IM (2002) Protein phosphatase 1 is a molecular constraint on learning and memory. Nature 418:970-975.

Guzowski JF, Lyford GL, Stevenson GD, Houston FP, McGaugh JL, Worley PF, Barnes CA (2000) Inhibition of activity-dependent arc protein expression in the rat hippocampus impairs the maintenance of long-term potentiation and the consolidation of long-term memory. J Neurosci 20:3993-4001.

Hock C, Konietzko U, Streffer JR, Tracy J, Signorell A, Muller-Tillmanns B, Lemke U, Henke K, Moritz E, Garcia E, Wollmer MA, Umbricht D, de Quervain DJ, Hofmann M, Maddalena A, Papassotiropoulos A, Nitsch RM (2003) Antibodies against beta-amyloid slow cognitive decline in Alzheimer's disease. Neuron 38:547-554.

Holcomb L, Gordon MN, McGowan E, Yu X, Benkovic S, Jantzen P, Wright K, Saad I, Mueller R, Morgan D, Sanders S, Zehr C, O'Campo K, Hardy J, Prada CM, Eckman C, Younkin S, Hsiao K, Duff K (1998) Accelerated Alzheimer-type phenotype in transgenic mice carrying both mutant amyloid precursor protein and presenilin 1 transgenes. Nat Med 4:97-100.

Hsieh H, Boehm J, Sato C, Iwatsubo T, Tomita T, Sisodia S, Malinow R (2006) AMPAR removal underlies Abeta-induced synaptic depression and dendritic spine loss. Neuron 52:831-843.

Jones MW, Errington ML, French PJ, Fine A, Bliss TV, Garel S, Charnay P, Bozon B, Laroche S, Davis S (2001) A requirement for the immediate early gene Zif268 in the expression of late LTP and long-term memories. Nat Neurosci 4:289-296.

Jouvenceau A, Hedou G, Potier B, Kollen M, Dutar P, Mansuy IM (2006) Partial inhibition of PP1 alters bidirectional synaptic plasticity in the hippocampus. Eur J Neurosci 24:564-572.

Kelly BL, Ferreira A (2006) beta-Amyloid-induced dynamin 1 degradation is mediated by $N$-methyl-D-aspartate receptors in hippocampal neurons. J Biol Chem 281:28079-28089.

Klein WL (2002) Abeta toxicity in Alzheimer's disease: globular oligomers (ADDLs) as new vaccine and drug targets. Neurochem Int 41:345-352.

Klyubin I, Walsh DM, Lemere CA, Cullen WK, Shankar GM, Betts V, Spooner ET, Jiang L, Anwyl R, Selkoe DJ, Rowan MJ (2005) Amyloid beta protein immunotherapy neutralizes Abeta oligomers that disrupt synaptic plasticity in vivo. Nat Med 11:556-561.

Knobloch M, Konietzko U, Krebs DC, Nitsch RM (2007) Intracellular
B wt control mice

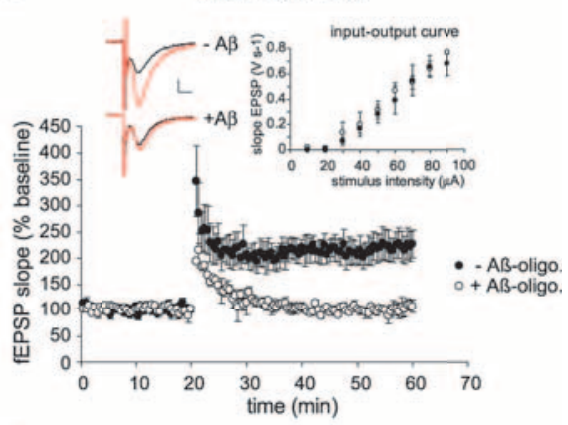

D $\quad 1^{*}$ transgenic mice

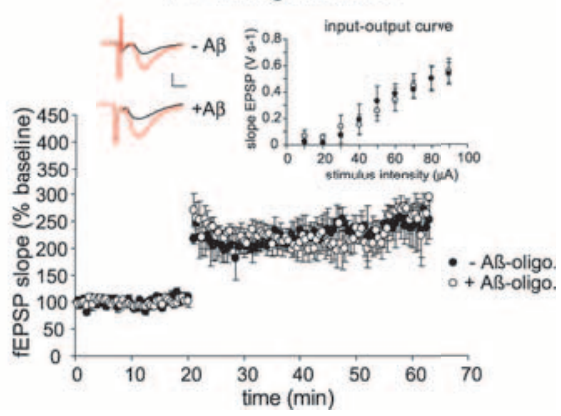

Figure 3. Endogenous PP1 inhibition in vivo confers resistance to $A \beta$ oligomer-mediated toxicity. $A$, Electron microscopy of 列 mice $(n=5)$. Right inset, Basal transmission is not affected. Left insets, Individual fEPSP traces with and without application of (red) LTP induction. Calibration: 0.6 mV, 5 ms. Error bars represent SEM. oligo., Oligomer.

Abeta and cognitive deficits precede beta-amyloid deposition in transgenic arcAbeta mice. Neurobiol Aging, in press.

Lambert MP, Barlow AK, Chromy BA, Edwards C, Freed R, Liosatos M, Morgan TE, Rozovsky I, Trommer B, Viola KL, Wals P, Zhang C, Finch CE, Krafft GA, Klein WL (1998) Diffusible, nonfibrillar ligands derived from Abeta1-42 are potent central nervous system neurotoxins. Proc Natl Acad Sci USA 95:6448-6453.

Lesne S, Koh MT, Kotilinek L, Kayed R, Glabe CG, Yang A, Gallagher M, Ashe $\mathrm{KH}$ (2006) A specific amyloid-beta protein assembly in the brain impairs memory. Nature 440:352-357.

Lin KF, Chang RC, Suen KC, So KF, Hugon J (2004) Modulation of calci$\mathrm{um} /$ calmodulin kinase-II provides partial neuroprotection against betaamyloid peptide toxicity. Eur J Neurosci 19:2047-2055.

Link W, Konietzko U, Kauselmann G, Krug M, Schwanke B, Frey U, Kuhl D (1995) Somatodendritic expression of an immediate early gene is regulated by synaptic activity. Proc Natl Acad Sci USA 92:5734-5738.

Lisman J, Schulman H, Cline H (2002) The molecular basis of CaMKII function in synaptic and behavioural memory. Nat Rev Neurosci 3:175-190.

Mansuy IM, Shenolikar S (2006) Protein serine/threonine phosphatases in neuronal plasticity and disorders of learning and memory. Trends Neurosci 29:679-686.

Michalon A, Koshibu K, Baumgartel K, Spirig DH, Mansuy IM (2005) Inducible and neuron-specific gene expression in the adult mouse brain with the rtTA2S-M2 system. Genesis 43:205-212.

Oddo S, LaFerla FM (2006) The role of nicotinic acetylcholine receptors in Alzheimer's disease. J Physiol (Paris) 99:172-179.

Oddo S, Caccamo A, Shepherd JD, Murphy MP, Golde TE, Kayed R, Metherate R, Mattson MP, Akbari Y, LaFerla FM (2003) Triple-transgenic model of Alzheimer's disease with plaques and tangles: intracellular Abeta and synaptic dysfunction. Neuron 39:409-421.

Rowan MJ, Klyubin I, Cullen WK, Anwyl R (2003) Synaptic plasticity in 
animal models of early Alzheimer's disease. Philos Trans R Soc Lond B Biol Sci 358:821-828.

Rowan MJ, Klyubin I, Wang Q, Anwyl R (2005) Synaptic plasticity disruption by amyloid beta protein: modulation by potential Alzheimer's disease modifying therapies. Biochem Soc Trans 33:563-567.

Schenk DB, Seubert P, Grundman M, Black R (2005) A beta immunotherapy: lessons learned for potential treatment of Alzheimer's disease. Neurodegener Dis 2:255-260.

Selkoe DJ (2002) Alzheimer's disease is a synaptic failure. Science 298: $789-791$.

Snyder EM, Nong Y, Almeida CG, Paul S, Moran T, Choi EY, Nairn AC, Salter MW, Lombroso PJ, Gouras GK, Greengard P (2005) Regulation of NMDA receptor trafficking by amyloid-beta. Nat Neurosci 8:1051-1058.

Strack S, Barban MA, Wadzinski BE, Colbran RJ (1997) Differential inactivation of postsynaptic density-associated and soluble $\mathrm{Ca} 2+/$ calmodulindependent protein kinase II by protein phosphatases 1 and 2A. J Neurochem 68:2119-2128.
Takahashi RH, Milner TA, Li F, Nam EE, Edgar MA, Yamaguchi H, Beal MF, Xu H, Greengard P, Gouras GK (2002) Intraneuronal Alzheimer abeta42 accumulates in multivesicular bodies and is associated with synaptic pathology. Am J Pathol 161:1869-1879.

Tzingounis AV, Nicoll RA (2006) Arc/Arg3.1: linking gene expression to synaptic plasticity and memory. Neuron 52:403-407.

Walsh DM, Klyubin I, Fadeeva JV, Cullen WK, Anwyl R, Wolfe MS, Rowan MJ, Selkoe DJ (2002) Naturally secreted oligomers of amyloid beta protein potently inhibit hippocampal long-term potentiation in vivo. Nature 416:535-539.

Wang HW, Pasternak JF, Kuo H, Ristic H, Lambert MP, Chromy B, Viola KL, Klein WL, Stine WB, Krafft GA, Trommer BL (2002) Soluble oligomers of beta amyloid (1-42) inhibit long-term potentiation but not long-term depression in rat dentate gyrus. Brain Res 924:133-140.

Worley PF, Christy BA, Nakabeppu Y, Bhat RV, Cole AJ, Baraban JM (1991) Constitutive expression of zif268 in neocortex is regulated by synaptic activity. Proc Natl Acad Sci USA 88:5106-5110. 